\title{
Pengaruh Motivasi Belajar dan Kemampuan Menyimak terhadap Keterampilan Menulis Teks Pidato (Survei pada SMA Negeri di Kota Cilegon)
}

\author{
Agnes Jatu Resani Seno ${ }^{1)}$ \\ Universitas Indraprasta PGRI \\ Jalan Nangka No. 58 C/TB. Simatupang, Tanjung Barat, Jakarta Selatan 12530 \\ Sumaryoto ${ }^{2)}$ \\ Universitas Indraprasta PGRI \\ Jalan Nangka No. 58 C/TB. Simatupang, Tanjung Barat, Jakarta Selatan 12530 \\ agnes.jatu86@gmail.com ${ }^{1)}$
}

\begin{abstract}
The objective of this research is to analyze and to assess the hypothesis about the Effect on Learning Motivation and Deep Listening on The Skill of Writing Speech Text. The hypothesis of the research consists of: 1) There is significant effect learning motivation on the skill of writing speech text . 2) There is significant effect of deep listening on the skills of writing short stories. 3) There is significant effect of interaction between learning motivation and interest in learning on the skills of writing speech text. The Method used in this research is survey method. The population is the 11th grade students of SMA in Cilegon, consist of 91 students. The sampling technique used is cluster random sampling. The statistics analysis used in this research is multiple linear regression. The results conclude: 1) There is a significant influence of Learning Motivation and Deep Listening along together with the skill of writing speech text in state junior high school students of Cilegon district. This is be evidenced by the value of Sig =0,000 < 0,05 and Farithmetic 11,078.2) There is a significant influence on the Learning Motivation to the skill of writing speech text in state junior high scool students of Cilegon distric. This is be evidenced by the value Sig=0,001 $<0,05$ and Tarithmetic. 3,515. 3)There is a significant influence of deep listening to the skill of writing speech text in state junior high scool students of Cilegon distric. This is be evidenced by the value Sig= $0,004<0,05$ and Tarithmetic2,985.
\end{abstract}

Keywords: Learning Motivation, Deep Listening, Speech Text Writing Skills

\begin{abstract}
Abstrak
Tujuan dari penelitian ini adalah untuk mengetahui hasil analisis mengenai: 1) Pengaruh motivasi belajar dan kemampuan menyimak secara bersama-sama terhadap keterampilan menulis pidato Siswa SMA di Kota Cilegon. 2) Pengaruh motivasi belajar terhadap keterampilan menulis teks pidato Siswa SMA Negeri Kota di Cilegon. 3) Pengaruh kemampuan menyimak terhadap keterampilan menulis teks pidato Siswa SMA Negeri Kota di Cilegon. Sampel yang digunakan dalam penelitian ini adalah sebanyak 91 siswa, yang dilakukan dengan teknik sampling cluster random sampling. Analisis data menggunakan analis Regresi Linear Berganda. Hasil penelitian menunjukkan: 1) Terdapat pengaruh yang signifikan motivasi belajar dan kemampuan menyimak secara bersama-sama terhadap keterampilan menulis teks pidato pada siswa SMA negeri di Kota Cilegon. Hal ini dibuktikan dengan nilai Sig $=0.000<0,05$ dan Fhitung $=11$, 078. 2) Terdapat pengaruh yang signifikan motivasi belajar terhadap keterampilan menulis teks pidato pada siswa SMA negeri di Kota Cilegon. Hal ini dibuktikan dengan nilai Sig $=0.001<0,05$ dan thitung = 3,515. 3) Terdapat pengaruh yang signifikan kemampuan menyimak terhadap keterampilan menulis teks pidato pada siswa SMA negeri di Kota Cilegon. Hal ini dibuktikan nilai Sig $=0.004<0,05$ dan
\end{abstract}

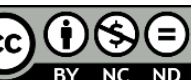

Creative Commons Attribution-NonCommercial-NoDerivatives 4.0 International License 
thitung $=2,985$. Hasil penelitian ini berguna untuk meningkatkan kualitas pembelajaran dan meningkatkan keterampilan menulis teks pidato di tingkat SMA.

Kata Kunci: Motivasi Belajar, Kemampuan Menyimak, Keterampilan Menulis Teks Pidato

\section{PENDAHULUAN}

Keterampilan dan kemahiran berbahasa perlu dikuasai oleh siswa karena diperlukan dalam berinteraksi di masyarakat. Dengan memiliki keterampilan berbahasa, siswa dapat memahami pikiran, perasaan, gagasan, fakta yang disampaikan oleh seseorang kepada orang lain atau dirinya sendiri. Keterampilan berbahasa memang sangat kompleks dan luas. Bila kita cermati lebih jauh hampir setiap bidang kehidupan manusia tidak pernah luput dari aspek kebahasaan.

Banyak profesi dalam masyarakat yang keberhasilannya bergantung pada keterampilan berbahasa yang dimiliki seseorang. Bagi seorang guru, apabila keterampilan berbicara guru tidak memadai, maka di pihak lain siswa akan kesulitan menangkap materi pelajaran yang disampaikan secara lisan karena keterampilan berbicara guru tidak memadai atau keterampilan siswa rendah dalam mendengarkan. Begitu juga pengetahuan dan kebudayaan tidak akan dapat diwariskan kepada generasi berikutnya apabila kita tidak memiliki keterampilan menulis. Demikian juga sebaliknya kita tidak dapat memperoleh pengetahuan yang disampaikan para pakar apabila kita tidak memiliki keterampilan membaca yang memadai.

Keterampilan berbahasa meliputi empat aspek keterampilan yang saling mendukung, yaitu menyimak, berbicara, membaca, dan menulis. Dari keempat keterampilan berbahasa dan bersastra, menulis merupakan keterampilan yang paling kompleks atau paling sulit, baik dalam hal keadaannya maupun pelaksanaannya. Hal tersebut didukung oleh pernyataan Widyamartaya (2003:9), yang menjelaskan bahwa keterampilan menulis merupakan suatu keterampilan berbahasa yang dipergunakan untuk berkomunikasi secara tidak langsung, tidak secara bertatap muka, dan merupakan kegiatan produktif ekspresif. Menulis adalah kegiatan kompleks karena menulis merupakan keseluruhan rangkaian kegiatan seseorang mengungkapkan gagasan dan menyampaikannya melalui bahasa tulis kepada pembaca untuk dipahami.

Keterampilan siswa dalam menulis dapat dilihat dalam hasil tulisan siswa seperti dalam teks pidato karangan siswa. Siswa dapat dikatakan mampu menulis bila dalam tulisannya sudah memuat aspek-aspek keterampilan menulis yang seharusnya ada dalam sebuah tulisan. Namun, pada kenyataannya, dalam hasil tulisan siswa belum memuat semua aspek keterampilan menulis tersebut. Hal ini menunjukkan bahwa menulis merupakan suatu keterampilan yang sukar karena siwa belum mampu menuangkan ide dalam bentuk tulisan secara baik. Kesukaran tersebut dapat berupa siswa tidak dapat menentukan topik tulisan, menyusun kalimat dengan baik dan benar sehingga kurangnya kepaduan antarkalimat dan paragraf serta kurangnya penguasaan kosakata. Kesukaran-kesukaran yang dialami siswa tersebut mengakibatkan kualitas tulisan siswa menjadi tidak baik.

Pada dasarnya pidato merupakan kegiatan berbicara, tetapi perlu diperhatikan bahwa sebelum memulai kegiatan berpidato secara lisan, seseorang 
bisa menuliskan terlebih dahulu pidato yang akan disampaikan, lalu dibacakan sesuai dengan teks yang telah ditulis. Metode ini disebut dengan metode naskah (manuskrip). Metode naskah sering digunakan dalam pidato kenegaraan atau dalam kegiatan yang bersifat formal. Menuliskan naskah pidato terlebih dahulu ini bertujuannya agar ide atau gagasan yang ingin disampaikan dapat lebih runtut dan komplek.

Keterampilan berpidato merupakan salah satu bentuk komunikasi yang banyak digunakan untuk berbagai keperluan. Seseorang yang ingin terampil dalam berpidato, ia harus berlatih dengan baik. Hal yang tak kalah pentingnya dalam berpidato adalah konsep diri, yaitu keterampilan pada diri seseorang dengan dukungan menyiapkan diri dan mampu menyimak. Berhasil atau tidaknya seseorang dalam berpidato harus diimbangi dengan pengetahuan yang luas, perbendaharaan kata yang cukup, memahami materi yang akan disampaikan, penyampaian materinya, penguasaan bahasa, kesesuaian gerakan dengan materi yang akan disampaikan, dan lainnya.

Hasnun (2005:217) menjelaskan berpidato adalah berbicara dihadapan umum. Namun tidak semua pembicaraan di hadapan umum namanya pidato. Berpidato merupakan bentuk kegiatan berbahasa yang dinyatakan secara lisan dalam situasi tertentu kepada orang tertentu. Tujuan berpidato dapat beragam bergantung dari keadaan, situasi, dan apa yang dikehendaki pembicara. Tujuannya ada yang bersifat instruktif, rekreatif, dan persuasif. Pidato yang bersifat instruktif isinya memberitahukan hal tertentu kepada pendengar. Tujuan pidato rekreatif adalah menghibur dan menyenangkan pendengar. Tujuan pidato persuasif adalah mendorong pendengar untuk memiliki semangat, kemauan, dan keyakinan sehingga melakukan sesuatu sebagaimana dikehendaki pembicara.

Banyak kendala yang sering dialami siswa dalam menguasai suatu keterampilan berbahasa, khususnya dalam hal menulis. Kendala yang dialami siswa disebabkan oleh beberapa faktor. Faktor dari siswa itu sendiri yang paling dominan dalam proses pembelajaran menulis. Faktor yang mempengaruhi rendahnya keterampilan siswa menulis antara lain bakat, minat, penguasaan kosa kata, keterampilan berbicara, minimnya pengetahuan tentang menulis, dan yang paling dominan adalah motivasi belajar yang rendah.

Motivasi siswa yang rendah terhadap keterampilan menulis pidato disebabkan karena mereka merasa kurang atau belum membutuhkan keterampilan menulis pidato tersebut. Uno (2011:3) menjelaskan motivasi berasal dari kata "motif" yang dapat diartikan sebagai kekuatan yang terdapat dalam diri individu yang menyebabkan individu tersebut bertindak atau berbuat. Motif adalah daya penggerak dalam diri seseorang untuk melakukan aktivitas tertentu demi mencapai tujuan. Dengan demikian, motivasi merupakan dorongan yang terdapat dalam diri seseorang untuk berusaha mengadakan perubahan tingkah laku yang lebih baik dalam memenuhi kebutuhannya. Kedudukan mereka sebagai pelajar membuat mereka merasa keterampilan menulis pidato belum mereka butuhkan di dalam kehidupan mereka, padahal siswa seharusnya menyadari bahwa mereka adalah calon penerus bangsa yang nantinya bisa menjadi pemimpin. Sebagai seorang pemimpin tentunya seseorang harus cakap berbicara di depan khalayak ramai dan untuk memiliki keterampilan tersebut tidak dapat dipelajari dengan singkat,

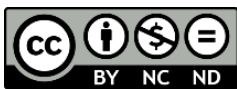

Creative Commons Attribution-NonCommercial-NoDerivatives 4.0 International License 
tentunya harus melalui proses pembelajaran yang berkesinambungan dimulai dari usia remaja.

Tarigan (2008:4) yang menjelaskan bahwa keterampilan menulis tidak akan datang secara otomatis tetapi harus melalui latihan dan dan praktik yang banyak dan teratur. Dengan memiliki keterampilan menulis, akan memudahkan seseorang untuk mengomunikasikan gagasan, ide, pikiran, dan pengalamannya dalam berbagai bentuk tulisan. Masyarakat Indonesia lebih menyukai menonton televisi ataupunn internet daripada membaca buku. Ditambah lagi banyaknya penelitian yang mengatakan bahwa budaya membaca masyarakat Indonesia masih sangat rendah. Oleh karena itu, motivasi audiovisual harus juga diperhatikan oleh guru dalam upaya meningkatkan keterampilan menulis teks pidato siswa.

Keterampilan berbahasa siswa hendaknya diperhatikan oleh guru dalam upaya meningkatkan keterampilan menulis. Kemampuan menyimak juga rupanya sangat berpengaruh dalam meningkatkan keterampilan siswa menulis teks pidato karena apabila mendengarkan baik-baik orang berbicara, kita dapat menangkap serangkaian satuan bahasa yang saling berhubungan dengan disertai jeda dan hentian tertentu pada setiap satuan dengan pola lagu (intonasi) tertentu. Apabila pembicaraan itu kita tuliskan, kita dapat melihat satuan-satuan bahasa yang saling berhubungan itu tertulis terpisah-pisah dan disertai beberapa tanda titik, tanda koma, dan tanda tanya sebagai wacana berupa teks yang dapat kita baca.

Hermawan (2012 : 30) yang menjelaskan bahwa Menyimak merupakan sebuah keterampilan yang kompleks yang memerlukan ketajaman perhatian, konsentrasi, sikap mental yang aktif dan kecerdasan dalam mengasimilasi serta menerapkan setiap gagasan. Dalam pembelajaran Bahasa Indonesia keterampilan siswa dalam menyimak masih kurang diperhatikan. Hal tersebut dibuktikan dengan tidak adanya kompetensi dasar dalam kurikulum yang mengacu pada kemampuan menyimak.

Berdasarkan uraian di atas, pokok masalah yang diteliti dirumuskan dalam pertanyaan sebagai berikut :1) Apakah terdapat pengaruh motivasi belajar dan kemampuan menyimak secara bersama-sama terhadap keterampilan menulis teks pidato Siswa SMA Negeri di Kota Cilegon? 2) Apakah terdapat pengaruh motivasi belajar terhadap keterampilan menulis teks pidato Siswa SMA Negeri di Kota Cilegon? 3) Apakah terdapat pengaruh kemampuan menyimak terhadap keterampilan menulis teks pidato Siswa SMA Negeri di Kota Cilegon?

Tujuan penelitian ini adalah untuk mengetahui: 1) Pengaruh motivasi belajar dan kemampuan menyimak secara bersama-sama terhadap keterampilan menulis pidato Siswa SMA di Kota Cilegon. 2)Pengaruh motivasi belajar terhadap keterampilan menulis teks pidato Siswa SMA Negeri Kota di Cilegon. 3) Pengaruh kemampuan menyimak terhadap keterampilan menulis teks pidato Siswa SMA Negeri Kota di Cilegon.

\section{METODE}

Metode yang digunakan dalam penelitian ini adalah metode survei. Teknik analisis yang digunakan adalah analisis regresi Linier Berganda. Penelitian ini 
dilaksanakan di SMA Negeri di Kota Cilegon, pada bulan September sampai dengan bulan Desember 2020. Jumlah sampel dalam penelitian ini sebanyak 91 siswa yang dipilih dengan teknik cluster sampling. Hubungan antara ketiga variabel tersebut dapat digambarkan sebagai berikut:

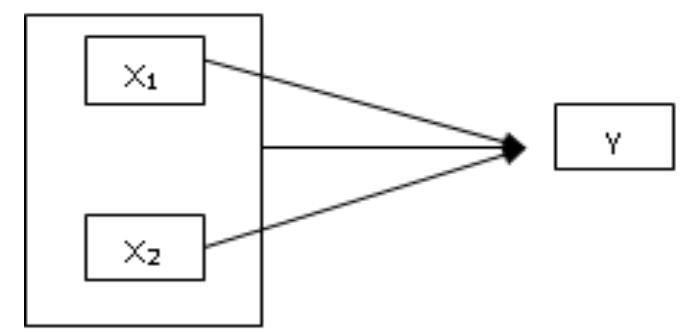

\section{Gambar 1. Konstelasi Hubungan Antar Variabel}

Keterangan

$\mathrm{XI}=$ Motivasi Belajar

$\mathrm{X} 2=$ Kemampuan Menyimak

$\mathrm{Y} \quad=$ Keterampilan menulis teks pidato

\section{HASIL DAN PEMBAHASAN}

\section{Hasil}

Berdasarkan pengolahan data diperoleh hasil sebagai berikut:

Tabel 1. Hasil Perhitungan Koefisien Korelasi Pengaruh Variabel $X_{1}$ dan $X_{2}$ terhadap Variabel Y

\begin{tabular}{ccccc}
\hline Model & $\mathrm{R}$ & R Square & $\begin{array}{c}\text { Adjusted R } \\
\text { Square }\end{array}$ & $\begin{array}{c}\text { Std. Error of } \\
\text { the Estimate }\end{array}$ \\
\hline 1 & $.448^{\mathrm{a}}$ & .201 & .183 & 8.690 \\
\hline
\end{tabular}

a. Predictors: Kemampuan Menyimak, Motivasi Belajar

b. Dependent Variable: Keterampilan Menulis Teks Pidato

Tabel 2. Hasil Perhitungan Pengujian Signifikansi Koefisien Regresi Pengaruh $X_{1}$ dan $X_{2}$ terhadap Variabel $Y$

\begin{tabular}{|c|c|c|c|c|c|c|}
\hline & Model & $\begin{array}{l}\text { Sum of } \\
\text { Squares }\end{array}$ & $\mathrm{df}$ & $\begin{array}{l}\text { Mean } \\
\text { Square }\end{array}$ & $\mathrm{F}$ & Sig. \\
\hline \multirow{3}{*}{1} & Regression & 1673.077 & 2 & 836.539 & 11.078 & $.000^{\mathrm{b}}$ \\
\hline & Residual & 6645.055 & 88 & 75.512 & & \\
\hline & Total & 8318.132 & 90 & & & \\
\hline
\end{tabular}

a. Dependent Variable: Keterampilan Menulis Teks Pidato

b. Predictors: (Constant), kemampuan Menyimak, Motivasi belajar 
Tabel 3. Hasil Perhitungan Persamaan Regresi Ganda Variabel $X_{1}$ dan $X_{2}$ terhadap Variabel Y

\begin{tabular}{lrrrrr}
\hline \multirow{2}{*}{ Model } & \multicolumn{2}{c}{$\begin{array}{c}\text { Unstandardized } \\
\text { Coefficients }\end{array}$} & $\begin{array}{c}\text { Standadized } \\
\text { Coefficients }\end{array}$ & t & Sig. \\
\cline { 2 - 4 } & \multicolumn{1}{c}{$\mathrm{B}$} & \multicolumn{1}{c}{ Std. Error } & \multicolumn{2}{c}{ Beta } & \\
\hline (Constant) & 24.385 & 10.871 & & 2.243 & .027 \\
Motivasi Belajar & .286 & .081 & .335 & 3.515 & .001 \\
Kemampuan Menyimak & .259 & .087 & .285 & 2.985 & .004 \\
\hline
\end{tabular}

a. Dependent Variable: Keterampilan Menulis Teks Pidoato

\section{Pembahasan}

Pengaruh Motivasi Belajar ( $\left.\mathrm{X}_{1}\right)$ dan Kemampuan Menyimak $\left(\mathrm{X}_{2}\right)$ secara Bersama-Sama terhadap Keterampilan Menulis Teks Pidato (Y)

Dari deskripsi data setelah dilakukan analisis korelasi diperoleh koefisien korelasi sebesar 0,448 setelah dilakukan pengujian dengan program SPSS 20.0 terbukti bahwa koefisien korelasi tersebut signifikan. Hal ini berarti bahwa terdapat pengaruh variabel bebas $\mathrm{X}_{1}$ (motivasi belajar) dan $\mathrm{X}_{2}$ (kemampuan menyimak) secara bersama-sama terhadap variabel terikat $\mathrm{Y}$ (keterampilan menulis teks pidato).

Berdasarkan hasil analisis regresi diperoleh persamaan garis regresi $\widehat{\mathbf{Y}}=$ $24,385+0,286 X_{1}+0,259 X 2$. Nilai konstanta $=24,385$ menunjukkan bahwa dengan motivasi belajar dan kemampuan menyimak paling rendah sulit bagi siswa tersebut untuk bisa terampil menulis teks pidato yang baik, sedangkan nilai koefisien regresi sebesar 0,286 dan 0,259 menunjukkan bahwa terdapat pengaruh positif variabel bebas $\mathrm{X}_{1}$ (motivasi belajar) dan $\mathrm{X}_{2}$ (kemampuan menyimak) secara bersama-sama terhadap variabel terikat $\mathrm{Y}$ (keterampilan menulis teks pidato). Angka koefisien regresi tersebut juga menunjukkan bahwa setiap ada kenaikan satu nilai motivasi belajar maka akan terdapat kenaikan keterampilan menulis teks pidato sebesar 0,286 dan setiap ada kenaikan satu penguasaan kemampuan menyimak maka akan terdapat kenaikan keterampilan menulis teks pidato sebesar 0,259. Setiap kenaikan satu unit motivasi belajar dan sekaligus dengan kenaikan satu unit penguasaan kemampuan menyimak akan diikuti dengan kenaikan keterampilan menulis teks pidato $0,545(=0,286+0,259)$ unit.

Dari pengujian signifikansi regresi diperoleh nilai $\mathrm{Sig}=0.000$ dan $\mathbf{F}$ hitung $=$ 11,078 sedangkan $\mathbf{F}_{\text {tabel }}=3,10$, karena nilai Sig $<0,05$ dan $F_{\text {hitung }}>F_{\text {tabel }}$ maka $H_{0}$ ditolak yang berarti bahwa koefisien regresi tersebut signifikan. Dengan kata lain bahwa terdapat pengaruh motivasi belajar $\left(\mathrm{X}_{1}\right)$ dan kemampuan menyimak $\left(\mathrm{X}_{2}\right)$ secara bersama-sama terhadap keterampilan menulis teks pidato $(\mathrm{Y})$.

Hasil penelitian di atas menyimpulkan bahwa motivasi belajar dan kemampuan menyimak secara bersama-sama telah memberikan pengaruh positif terhadap peningkatan keterampilan menulis teks pidato siswa SMA Negeri di Kota Cilegon. Hal ini mengandung arti bahwa motivasi belajar dan kemampuan menyimak telah memberikan pengaruh yang signifikan terhadap peningkatan keterampilan menulis teks pidato siswa SMA Negeri di Kota Cilegon. 
Kemampuan menulis erat kaitannya dengan kemampuan seseorang dalam menuangkan ide dan gagsan berupa paparan tentang suatu permasalahan yang dihadapi. Nurgiyantoro (1987 : 196) menjelaskan kemampuan menulis adalah kemampan bersifat produktif. Aktivitas menulis merupakan suatu bentuk manifestasi kemampuan dan keterampilan berbahasa paling akhir dikuasai pelajar bahasa setelah kemampuan lain seperti mendengarkan, berbicara, membaca.

Lado dalam tarigan (2008:22) menjelaskan bahwa menulis adalah menempatkan symbol-simbol grafik yang menggambarkan suatu bahasa yang dimengerti oleh seseorang. Pada prinsipnya, fungsi utama menulis adalah sebagai alat komunikasi yang tidak langsung.

Teks pidato merupakan teks yang berisi informasi dan ajakan seseorang untuk melakukan hal yang sesuai dengan isi informasi yang dituliskan. Dalam pidato bukan saja hanya menjelaskan suatu informasi tetapi bagaimana informasi tersebut dapat diterapkan dan dilakukan sesuai dengan tujuan pidato. Ketika menulis teks pidato siswa harus memerhatikan beberapa struktur dan aspek pidato karena tujuan utama dari penulisan teks pidato adalah bagaimana teks tersebut dapat disampaikan di depan khalayak umum.

Untuk dapat menghasilkan sebuah teks pidato yang baik, tentunya seseorang memerlukan motivasi belajar yang tinggi dan kemampuan menyimak yang baik agar teks pidato yang dihasilkan dapat dirasakan dan diterima oleh pembacanya. Oleh karena itu, motivasi belajar dan kemampuan menyimak secara bersama-sama berpengaruh positif terhadap keterampilan menulis teks pidato siswa.

\section{Pengaruh Motivasi Belajar ( $\mathrm{X}_{1}$ ) terhadap Keterampilan Menulis Teks Pidato} (Y)

Dari pengujian hipotesis diperoleh bahwa nilai $\operatorname{Sig}=0,001$ dan $t_{\text {hitung }}=3$, 515 sedangkan $t_{\text {tabel }}=1,987$. Karena nilai $\operatorname{Sig}<0,05$ dan $t_{\text {hitung }}>t_{\text {tabel. }}$. Maka $\mathrm{H}_{0}$ ditolak yang berarti terdapat pengaruh yang signifikan variabel bebas $\mathrm{X}_{1}$ (motivasi belajar) terhadap variabel terikat Y (keterampilan menulis teks pidato).

Menurut pendapat para ahli, motivasi belajar merupakan dorongan dari dalam diri seseorang atau faktor yang menimbulkan ketertarikan atau perhatian secara selektif yang menyebabkan dipilihnya suatu objek atau kegiatan yaitu menulis sebagai suatu kegiatan yang menguntungkan, menyenangkan atau mendatangkan kepuasan. Hasil analisis hubungan motivasi belajar dengan keterampilan menulis menunjukkan adanya hubungan positif yang signifikan antara kedua variabel.

Hal ini dapat diartikan bahwa semakin tinggi motivasi belajar siswa, maka semakin baik pula keterampilan menulisnya. Simpulan tersebut menjelaskan bahwa keterampilan menulis siswa terbukti berkaitan dengan motivasi belajar siswa. Motivasi belajar yang dimiliki siswa akan menjadi pendorong dalam kegiatan belajar, termasuk kegiatan belajar menulis.

Dengan motivasi yang tinggi, siswa akan senang, suka, dengan memiliki sikap ini siswa tidak akan merasa cepat bosan pada tugas yang diberikan oleh guru. Selain hal itu, siswa perlu memiliki sikap senang bekerja mandiri. Dengan hal ini akan membantu siswa dalam menanamkan sikap ulet atau pantang menyerah

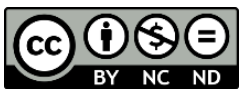


terhadap suatu masalah dalam belajarnya. Dengan adanya sikap yang tidak mudah menyerah, siswa akan terbiasa dalam menyelesaikan hambatan yang dihadapinya. Oleh karena itu, motivasi belajar yang baik akan menunjang keberhasilan siswa dalam meningkatkan keterampilan menulis yang baik pula.

Faktor internal siswa berupa motivasi memiliki peran penting dalam menentukan prestasi belajarnya, motivasi merupakan faktor penyebab lahirnya prestasi yang merupakan indikasi kualitas siswa didik tersebut. Dalam bidang pendidikan pengukuran keterampilan menulis memegang peranan yang sangat penting. Data hasil pengukuran memiliki arti penting baik bagi sekolah atau lembaga pendidikan, guru, maupun siswa dan orang tua atau masyarakat.

\section{Pengaruh Penguasaan Kemampuan Menyimak $\left(\mathbf{X}_{2}\right)$ terhadap Keterampilan Menulis Teks Pidato(Y)}

Dari pengujian hipotesis diperoleh bahwa nilai $\operatorname{Sig}=0,004$ dan $t_{\text {hitung }}=$ 2,985 , sedangkan $t_{\text {tabel }}=1,987$. Karena nilai $\operatorname{Sig}<0,05$ dan $t_{\text {hitung }}>t_{\text {tabel }}$ maka $\mathrm{H}_{0}$ ditolak yang berarti terdapat pengaruh yang signifikan variabel bebas $X_{2}$ (kemampuan menyimak) terhadap variabel Y (keterampilan menulis teks pidato).

Hasil analisis hubungan kemampuan menyimak dengan keterampilan menulis menunjukkan adanya hubungan positif yang signifikan antara kedua variabel. Hal ini dapat diartikan bahwa semakin baik kemampuan menyimak siswa, maka semakin baik pula keterampilan menulisnya. Simpulan tersebut menjelaskan bahwa keterampilan menulis siswa terbukti berkaitan dengan kemampuan menyimak siswa. Untuk meningkatkan kualitas simakannya siswa perlu memahami informasi yang terkandung di dalam simakannya. Selain hal itu, siswa perlu mengetahui arti kata dalam simakannya. Dengan mengetahui arti kata dalam setiap kalimat, maka akan mudah penyimak dalam menangkap informasi yang disampaikan oleh pembicara. Oleh karena itu, kemampuan siswa dalam hal memahami istilah-istilah dalam simakan perlu ditingkatkan. Dengan menyimak, siswa akan terlatih menerima pesan dan informasi yang datang dari luar yang berupa bunyi-bunyi bahasa. Selain hal tersebut di atas perlu meningkatkan pemahaman tentang pesan atau informasi yang tersirat dari simakan tersebut. Memahami informasi yang tersirat akan membantu siswa dalam meningkatkan kualitas hasil simakan. Kegiatan menyimak perlu adanya latihan yang rutin, bila hal itu sering dilakukan siswa, maka dengan sendirinya siswa akan bertambah pengetahuan dan wawasannya.

Pengetahuan dan wawasan yang diperkaya melalui kegiatan menyimak tersebut memiliki peranan yang sangat menguntungkan untuk bekal siswa dalan melakukan kegiatan menulis. Karena kegiatan menulis memerlukan penguasaan kosa kata yang lebih banyak, dengan penguasaan kosa kata yang banyak akan menjadkan keterampilan menulis siswa akan menjadi lebih baik. Oleh karena itu, penguasaan kemampuan menyimak dapat berpengaruh positif terhadap keterampilan menulis teks pidato Siswa SMA Negeri di kota Cilegon sehingga dapat hasil yang memuaskan. 


\section{SIMPULAN}

Berdasarkan pembahasan hasil penelitian pada bab sebelumnya, maka penelitian ini telah berhasil menjawab hipotesis yang diajukan. Dengan demikian kesimpulan dari hasil penelitian ini adalah:

1. Terdapat pengaruh yang signifikan motivasi belajar dan kemampuan menyimak secara bersama-sama terhadap keterampilan menulis teks pidato siswa SMA Negeri di Kota Cilegon. Hal ini dibuktikan dengan nilai Sig $=0.000<0.05$ dan Fhitung $=11.078$.

2. Terdapat pengaruh yang signifikan motivasi belajar terhadap keterampilan menulis teks pidato siswa SMA Negeri di Kota Cilegon.. Hal ini dibuktikan dengan nilai Sig $=0.001<0,05$ dan thitung $=3,515$.

3. Terdapat pengaruh yang signifikan kemampuan menyimak terhadap keterampilan menulis teks pidato siswa SMA Negeri di Kota Cilegon . Hal ini dibuktikan dengan nilai Sig $=0.004<0,05$ dan thitung $=2,985$.

\section{DAFTAR PUSTAKA}

Hasnun, A. (2005). Pedoman menulis untuk siswa SMP dan SMA. Yogyakarta: Andi.

Hermawan, H. (2012). Menyimak keterampilan komunikasi yang terabaikan. Yogyakarta: Graha Ilmu.

Nurgiyantoro, B. (1987). Penilaian dalam pengajaran bahasa dan sastra. Yogyakarta : BPFE.

Tarigan, H.G. (2008). Menulis sebagai suatu keterampilan berbahasa. Bandung : Angkasa.

Uno, H.B. (2011). Teori motivasi dan pengukurannya. Jakarta: Bumi Aksara. Widyamartaya, A. (2003). Seni menuangkan gagasan. Yogyakarta: Kanisius. 